\title{
DNase concentration assay to obtain DNA-free RNA from sugarcane leaves
}

\author{
J.A. Santos ${ }^{1}$, G.A. Luz ${ }^{2}$, K.P. Oliveira ${ }^{3}$, L.F. Oliveira ${ }^{4}$, A.S. Andrade Júnior ${ }^{4}$, \\ S.E.S. Valente ${ }^{1}$ and P.S.C. Lima ${ }^{4}$ \\ ${ }^{1}$ Departamento de Biologia, Universidade Federal do Piauí, Campus Ininga, \\ Teresina, PI, Brasil \\ ${ }^{2}$ Departamento de Agronomia, Universidade Federal do Piauí, Campus Ininga, \\ Teresina, PI, Brasil \\ ${ }^{3}$ Departamento de Biologia, Universidade Estadual do Piauí, Torquato Neto, \\ Teresina, PI, Brasil \\ ${ }^{4}$ Empresa Brasileira de Pesquisa Agropecuária, Embrapa Meio-Norte, Teresina, \\ PI, Brasil
}

Corresponding author: P.S.C. Lima

E-mail: paulo.costa-lima@embrapa.br

Genet. Mol. Res. 15 (4): gmr15049073

Received August 11, 2016

Accepted October 19, 2016

Published December 2, 2016

DOI http://dx.doi.org/10.4238/gmr15049073

Copyright $(\mathcal{C} 2016$ The Authors. This is an open-access article distributed under the terms of the Creative Commons Attribution ShareAlike (CC BY-SA) 4.0 License.

\begin{abstract}
The success of gene expression studies, protein synthesis, and construction of cDNA libraries directly depends on the purity and integrity of the RNA used in these tests, as even minor amounts of contaminant DNA $(<1 \%)$ can produce a false positive amplification signal in quantitative real-time PCR. For RNA contaminated with genomic DNA, an essential step in the studies on gene expression is the treatment of the RNA samples with DNase. This study was conducted to test three different concentrations of DNase I $(0.02,0.04$, and $0.06 \mu \mathrm{L} /$ ng of RNA), which were chosen based on the results of the RNA sample quantifications and as indicated by the manufacturer, to digest genomic
\end{abstract}


DNA present in the RNA samples extracted from sugarcane leaves with the Concert ${ }^{\mathrm{TM}}$ Plant RNA Reagent. The results showed that all three concentrations of DNase significantly reduced DNA concentrations. However, RNA was also degraded on DNase I treatment. In addition, the amount of DNA present in the RNA samples after purification with DNase I was sufficient for its amplification in the tests conducted with conventional PCR. Furthermore, the condition of RNA samples obtained after the treatments allowed for real-time PCR. Therefore, we concluded that $0.02 \mu \mathrm{L}$ DNase I was the ideal concentration for sugarcane RNA purification, as higher concentrations do not increase the efficiency of the genomic DNA digestion in RNA samples and only make the purification process more expensive. This study provides important information on the effect of high concentrations of DNase I and complements previous studies that have so far tested only the DNase concentration recommended by the manufacturer.

Key words: Deoxyribonuclease I; qRT-PCR; RNA purification; Saccharum

\section{INTRODUCTION}

Distributed in the tropics and subtropics, sugarcane (Saccharum spp) is one of the most important crops in the world for the production of sugar, ethanol, and biomass (Guo et al., 2014). According to the United States Department of Agriculture, the global harvest of sugarcane between October 2014 and September 2015 resulted in the production of about 175.6 million tons of sugar. This makes sugarcane an important object of study in breeding programs that aim at increasing sugar production by identifying genes for sucrose accumulation and stress resistance using quantitative real-time PCR (qRT-PCR) (Ling et al., 2014).

qRT-PCR has been widely adopted in clinical diagnostics and research laboratories because it allows for obtaining quantitative results as the reaction proceeds, which represents a breakthrough in terms of accuracy and reproducibility of DNA and RNA quantification processes (Novais and Pires-Alves, 2004).

The success of gene expression studies, protein synthesis, and construction of cDNA libraries directly depends on the purity and integrity of the RNA used in these tests (Tavares et al., 2011; Sah et al., 2014). Thus, a crucial stage that can determine the quality of the RNA is the selection of an efficient extraction method for obtaining adequate concentrations of RNA free of interfering compounds such as secondary metabolites, especially polyphenols and polysaccharides, present in some plants, proteins, genomic DNA, enzyme inhibitors, and residues of phenol or alcohol (Bustin and Nolan, 2004; de Paula et al., 2012).

The organic extraction method is one of the most common methods used for RNA isolation; particularly, methods that use organic solvents, such as phenol/guanidine isothiocyanate. However, the RNA isolated using this method is often contaminated with proteins, cellular components, organic solvents, salts, or ethanol. In addition, when using this method, special care has to be taken to avoid incomplete separation of organic and inorganic phases, which may increase the probability of obtaining RNA contaminated with genomic DNA (Tavares et al., 2011).

Genetics and Molecular Research 15 (4): gmr15049073 
For RNA contaminated with genomic DNA, an essential step in the studies on realtime PCR is the treatment of the RNA samples with DNase. The DNase treatment prevents the effects of the contaminating DNA in the cDNA synthesis process and the nonspecific amplifications that may interfere with the quantification of the target gene in a qPCR (OñateSánchez and Vicente-Carbajosa, 2008). According to Martel et al. (2002), even small amounts of contaminating DNA $(<1 \%)$ can produce a false positive amplification signal in RT-PCR.

Therefore, this study aimed at testing three different concentrations of DNase I to obtain DNA-free RNA from RNA samples extracted from sugarcane leaves, to determine which concentration of the enzyme would help obtain adequate concentration of purified RNA samples of quality for future studies on gene expression.

Because of the lack of DNase I assays testing different concentrations of the enzyme, this study is significant, as it provides information on the effect of high concentrations of DNase I $(0.02,0.04$, and $0.06 \mu \mathrm{L} / \mathrm{ng}$ RNA), which were chosen based on the results of the RNA sample quantifications and as indicated by the manufacturer. In addition, the results obtained from this assay complement previous studies that have so far tested only the DNase concentrations recommended by the manufacturer.

\section{MATERIAL AND METHODS}

\section{Sample collection}

Leaf tissue from three cultivars of sugarcane (cultivar $1=\mathrm{C} 1$, cultivar $2=\mathrm{C} 2$, and cultivar $3=\mathrm{C} 3$ ) were collected in triplicates for each cultivar from the experimental area of Departamento de Fitotecnia at Universidade Federal do Piauí, Brazil. The basal portion of the young leaves was collected and placed in $1.5 \mathrm{~mL}$ microcentrifuge tubes containing RNAlater ${ }^{\circledR}$ (Thermo Fisher Scientific, USA), a stabilizing solution used to prevent RNase activity. After collection, the samples were stored in a freezer at $-20^{\circ} \mathrm{C}$, and RNA was isolated the next day.

\section{RNA isolation}

RNA was isolated with the Concert ${ }^{\mathrm{TM}}$ Plant RNA Reagent (Invitrogen, Thermo Fisher Scientific, USA), using the organic method and according to the manufacturer instructions. However, some modifications were made. Leaf tissue $(100 \mathrm{mg})$ and $500 \mu \mathrm{L}$ Concert reagent (at $4^{\circ} \mathrm{C}$ ) were homogenized in $2 \mathrm{~mL}$ maceration tubes for $50 \mathrm{~s}$ at $5500 \mathrm{rpm}$ using Precellys ${ }^{\mathbb{R}} 24$ homogenizer (Bertin Technologies, USA).

After 5 min at $23^{\circ} \mathrm{C}$ the samples were centrifuged at $15,294 \mathrm{~g}$ and $4{ }^{\circ} \mathrm{C}$ for 5 min. The supernatant was transferred to a new tube, and $100 \mu \mathrm{L} 5 \mathrm{M} \mathrm{NaCl}$ and $300 \mu \mathrm{L}$ chloroform were added to the tube. The mixture was centrifuged at 15,294 $\mathrm{g}$ and $4^{\circ} \mathrm{C}$ for $10 \mathrm{~min}$, and the supernatant was transferred to a new tube. An equal volume of absolute isopropanol was added to the supernatant in the tubes, which were inverted and allowed to stand for $10 \mathrm{~min}$ at $23^{\circ} \mathrm{C}$. The tubes were then centrifuged at $15,294 \mathrm{~g}$ and $4^{\circ} \mathrm{C}$ for 10 min, and the supernatant was discarded, leaving only the pellet. In the washing stage, 1 $\mathrm{mL} 75 \%$ ethanol was added to the tubes, which were then centrifuged at 15,294 $g$ for 10 min. The supernatant was discarded, the tubes were centrifuged for $1 \mathrm{~min}$, and the residual liquid was discarded. The samples were diluted in $50 \mu \mathrm{L}$ RNase-free water and were stored in a freezer.

Genetics and Molecular Research 15 (4): gmr15049073 


\section{Quantifications}

RNAextractions were quantified using threequantification methods: spectrophotometry, fluorimetry, and agarose gel electrophoresis. The first method was performed using a NanoDrop ${ }^{\mathrm{TM}} 2000$ (Thermo Scientific, USA), which can measure absorbance in the wavelength range of 190-840 $\mathrm{nm}$. Besides the RNA concentration, the equipment also calculated the $\mathrm{A}_{260 / 280}$ (relative absorbance of nucleic acids to proteins) and $\mathrm{A}_{260 / 230}$ (relative absorbance of nucleic acids to secondary metabolites and buffer components) ratios, with generally accepted values ranging from 1.8-2.2 and 1.7-2.2, respectively.

Although NanoDrop ${ }^{\mathrm{TM}}$ provides parameters to estimate the level of contamination in the samples, it does not distinguish between the various forms of nucleic acids (dsDNA, ssDNA, and RNA) and might overestimate the RNA quantitation. Therefore, we used the fluorometer Qubit ${ }^{\circledR} 2.0$ (Invitrogen), a more precise and specific equipment, as it involves the use of fluorescent dyes that bind specifically to dsDNA, ssDNA, or RNA and allows to distinguish between them. Finally, RNA analysis on $1 \%$ agarose gel was carried out to estimate its integrity.

\section{DNase I treatment}

To ensure the purity of the samples, the extracted RNA was treated with RNase-free DNase (DNase I, Amplification grade; Thermo Fisher Scientific, USA), to eliminate possible residues of genomic DNA. The DNase concentrations tested were $0.02(\mathrm{~T} 1=$ treatment 1$), 0.04$ $(\mathrm{T} 2=$ treatment 2$)$, and $0.06 \mu \mathrm{L} / \mathrm{ng} \mathrm{RNA}(\mathrm{T} 3=$ treatment 3$)$, which were defined based on the results of the RNA sample quantifications and as indicated by the manufacturer (Invitrogen): $1 \mu \mathrm{L}$ DNase I per 1 mg RNA.

A mixture of components used in the treatment with DNase was prepared as follows: $1 \mu \mathrm{L}$ RNA (sample), $1 \mu \mathrm{L}$ buffer, $0.02,0.04$, or $0.06 \mu \mathrm{L}$ DNase I, and RNase-free water to a final volume $10 \mu \mathrm{L}$. According to the manufacturer's protocol (Invitrogen), the samples were incubated for $15 \mathrm{~min}$ at $23^{\circ} \mathrm{C}$ to allow the functioning of DNase I. The enzyme was then inactivated by adding $1 \mu \mathrm{L} 25 \mathrm{mM}$ EDTA solution to the reaction mixture, followed by heating at $65^{\circ} \mathrm{C}$ for $10 \mathrm{~min}$ in Veriti ${ }^{\circledR}$ 96-Well Thermal Cycler (Applied Biosystems, USA).

\section{Efficiency of the DNase treatment}

To evaluate the efficiency of the DNase I treatment, the RNA samples treated with DNase I were used as samples for conventional PCR. The reagent quantities were estimated for a $10 \mu \mathrm{L}$ reaction volume: $6.025 \mu \mathrm{L}$ water, $0.55 \mu \mathrm{L}$ buffer, $0.44 \mu \mathrm{L}$ dNTPs, $0.165 \mu \mathrm{L} \mathrm{MgCl}_{2}, 0.02 \mu \mathrm{L}$ Taq DNA polymerase, $0.40 \mu \mathrm{L}$ sense primer, $0.40 \mu \mathrm{L}$ antisense primer, and $2.0 \mu \mathrm{L}$ RNA (sample). The reactions were performed in Veriti ${ }^{\circledR} 96-$ Well Thermal Cycler, and the reaction program used was: $2 \mathrm{~min}$ at $94^{\circ} \mathrm{C}$ for initial denaturation, 35 cycles of amplification corresponding to $15 \mathrm{~s}$ at $94^{\circ} \mathrm{C}, 30 \mathrm{~s}$ at $60^{\circ} \mathrm{C}$, and $1 \mathrm{~min}$ at $72^{\circ} \mathrm{C}$, followed by a final extension at $72^{\circ} \mathrm{C}$ for $5 \mathrm{~min}$.

The amplification fragments obtained were separated on $1.5 \%$ agarose gel in $0.5 \mathrm{X}$ TBE buffer, and the gels were stained with GelRed ${ }^{\mathrm{TM}}$ (1:1000; Uniscience, USA). The sizes of the amplified fragments were determined based on a $100 \mathrm{bp}$ DNA marker (Invitrogen). The products were visualized on an UV transilluminator and were photographed. The DNase I treatment was considered successful when no amplification bands for the target genes were seen on the gels.

Genetics and Molecular Research 15 (4): gmr15049073 
The primers (Table 1) used in the reactions were designed from sequences obtained from previous studies on gene expression in sugarcane under water and saline stresses (Oliveira, 2013; Guo et al., 2014). The primers were evaluated for the formation of secondary structures (loops, self-complementarity, dimers, and cross-dimers) using the NetPrimer software (Biosoft Primer, USA).

Table 1. Sequences of primers used in PCR.
\begin{tabular}{l|l|l}
\hline Gene & Forward primer $\left(5^{\prime}-3^{\prime}\right)$ & Reverse primer $\left(5^{\prime}-3^{\prime}\right)$ \\
\hline GAPDH & CACGGCCACTGGAAGCA & TCCTCAGGGTTCCTGATGCC \\
\hline HSP & CACGGCAACGGGCATCTG & TCGTAGCCCTTTCAGCAGTGG \\
\hline$P$ PII 10 & GCCCTCCTCGTCTACAACAC & TAGCATTACAGTGGGCATCG \\
\hline
\end{tabular}

Primers were designed using the Primer Express 3.0 software (Applied Biosystems).

\section{cDNA synthesis}

The first cDNA strand was synthesized from $9 \mu \mathrm{L}$ RNA treated with DNase. The reaction volume was $20 \mu \mathrm{L}$, and the High Capacity RNA-to-cDNA Kit (Applied Biosystems, USA) was used, following the manufacturer protocol.

\section{Analysis of DNase-treated RNA by qRT-PCR}

To verify the quality of the RNA treated with DNase I, qRT-PCR was performed. The mRNA expression levels were assessed by a SYBR Green assay using a StepOne ${ }^{\mathrm{TM}}$ RealTime PCR System (Applied Biosystems). PCR was performed in duplicates. The final reaction volume was $15 \mu \mathrm{L}$, containing $7.5 \mu \mathrm{L}$ SYBR Green/Master Mix, $0.45 \mu \mathrm{L}$ each primer (forward and reverse; $300 \mathrm{nM}), 1.5 \mu \mathrm{L} c \mathrm{cNA}$, and $5.1 \mu \mathrm{L}$ water.

The amplification conditions were: $50^{\circ} \mathrm{C}$ for $2 \mathrm{~min}, 95^{\circ} \mathrm{C}$ for $10 \mathrm{~min}$, and 40 cycles at $95^{\circ} \mathrm{C}$ for $15 \mathrm{~s}$ and $60^{\circ} \mathrm{C}$ for $1 \mathrm{~min}$. In addition, one dissociation curve stage was added to verify the specificity of the amplification. The target genes PSII 10 and $H S P$, a reference gene $G A P D H$, and negative controls were included.

\section{Data analysis}

The nonparametric variables, concentration and purity of the RNA, were analyzed by ANOVA complemented by $t$-test, assuming unequal variances. Both tests were performed using the Microsoft ${ }^{\circledR}$ Excel 2013 software.

\section{RESULTS}

\section{RNA concentration and quality before treatment with DNase}

The organic extraction method provided good amounts of nucleic acids of good quality, as was observed through spectrophotometry (Table 2). Furthermore, the fluorimetric RNA quantifications indicated differences in the concentrations of RNA from the three cultivars. The mean concentrations of the three replicates from the three cultivars $\mathrm{C} 1, \mathrm{C} 2$, and $\mathrm{C} 3$ were $26.1,13.24$, and $20.8 \mathrm{ng} / \mu \mathrm{L}$, respectively. 
Table 2. Quantification of the concentration and purity, using spectrophotometry, of the RNA samples isolated from the three cultivars of sugarcane $(\mathrm{C} 1, \mathrm{C} 2$, and $\mathrm{C} 3)$, before and after the DNase treatments.

\begin{tabular}{|c|c|c|c|c|c|c|c|c|c|c|c|c|}
\hline \multirow{2}{*}{ Sample } & \multicolumn{4}{|c|}{ Mean concentration $(\mathrm{ng} / \mu \mathrm{L})^{*}$} & \multicolumn{4}{|c|}{$\mathrm{A}_{260 / 280}$ ratio } & \multicolumn{4}{|c|}{$\mathrm{A}_{260 / 230}$ ratio } \\
\hline & Before treatment & $\mathrm{T} 1$ & $\mathrm{~T} 2$ & $\mathrm{~T} 3$ & Before treatment & T1 & T2 & $\mathrm{T} 3$ & Before treatment & T1 & $\mathrm{T} 2$ & $\mathrm{~T} 3$ \\
\hline $\mathrm{C} 1$ & 95.3 & 3.5 & 2.7 & 3.8 & 2.1 & 3.1 & 2.7 & 3.8 & 1.6 & 0.8 & 0.7 & 0.6 \\
\hline$\overline{\mathrm{C} 2}$ & 37.1 & 2.4 & 1.7 & 1.7 & 2.1 & 6.0 & 4.8 & 6.0 & 1.2 & 0.4 & 0.4 & 0.4 \\
\hline $\mathrm{C} 3$ & 75.6 & 3.3 & 3.4 & 3.2 & 2.1 & 2.5 & 2.9 & 4.8 & 0.7 & 0.6 & 0.5 & 0.6 \\
\hline
\end{tabular}

*The mean values refer to the mean of the values of the three replicates. T1, T2, and T3 indicate treatments with $0.02,0.04$, and $0.06 \mu \mathrm{L}$ DNase I, respectively.

Regarding the purity of the RNA, the results showed the effectiveness of the organic extraction method, which provided RNA samples free of protein contamination, as indicated by the $A_{260 / 280}$ ratio (Table 2). However, the RNA samples obtained showed indices of contamination with polysaccharides and/or polyphenols, as indicated by the $\mathrm{A}_{260 / 230}$ ratio. The results of the extractions and quantifications were confirmed on $1 \%$ agarose gel, illustrating the quality of the RNA obtained (Figure 1).

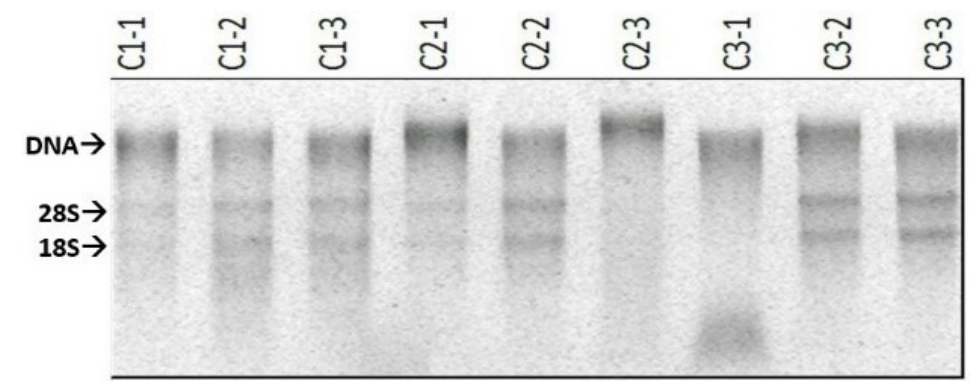

Figure 1. RNA fragments (28S and 18S) and DNA obtained by RNA extraction from three cultivars of sugarcane, with three replicates for each cultivar. $\mathrm{C} 1, \mathrm{C} 2$, and $\mathrm{C} 3$ indicate cultivars 1,2 , and 3 , which were treated with 0.02 , 0.04 , and $0.06 \mu \mathrm{L}$ DNase I (-1, -2 , and -3 , respectively).

\section{RNA concentration and quality after treatment with DNase}

There was a highly significant reduction $(\mathrm{P}=0.001)$ in the concentration of the nucleic acids after the DNase I treatment (Table 2). The percentages of reduction in the concentration of nucleic acids from $\mathrm{C} 1, \mathrm{C} 2$, and C3 samples were 96,95 , and $95 \%$, respectively. On the other hand, considering the differences in the final concentrations of the nucleic acids based on the three treatments (Table 2), no significant differences were observed between treatments 1 and $2(\mathrm{P}=0.98)$, treatments 1 and $3(\mathrm{P}=0.68)$, and treatments 2 and $3(\mathrm{P}=0.75)$.

The results of fluorimetric quantifications of the RNA and DNA concentrations indicated reduction in the RNA concentrations, before and after the treatments (Table 3). The RNA concentrations significantly decreased after the three treatments $(\mathrm{P}=0.000033)$. However, the reduction in RNA concentrations between the three treatments were not significant $(\mathrm{P}=0.85)$.

The results of the fluorimetric DNA quantifications (Table 3) indicated that even after treatment with DNase I, some DNA contamination was present in the RNA samples. However, significant reduction $(\mathrm{P}=0.005)$ in the DNA concentration was seen after treatment with DNase I. However, there were no significant differences in the DNase I activity between the three treatments $(\mathrm{P}=0.87)$, as the reductions in the DNA amounts were approximately equal. 
Table 3. Fluorimetric quantification of DNA and RNA extracted from the three cultivars of sugarcane (C1, C2, and C3), and reduction indices of DNA and RNA concentrations after treatment with different concentrations of DNase.

\begin{tabular}{|c|c|c|c|c|c|c|c|c|c|}
\hline \multirow[t]{3}{*}{ Parameter } & \multicolumn{9}{|c|}{ DNase concentration $(\mu \mathrm{L})$} \\
\hline & \multicolumn{3}{|c|}{$\mathrm{T} 1(0.02 \mu \mathrm{L})$} & \multicolumn{3}{|c|}{$\mathrm{T} 2(0.04 \mu \mathrm{L})$} & \multicolumn{3}{|c|}{ T3 $(0.06 \mu \mathrm{L})$} \\
\hline & $\mathrm{C} 1$ & $\mathrm{C} 2$ & $\mathrm{C} 3$ & $\mathrm{C} 1$ & $\mathrm{C} 2$ & $\mathrm{C} 3$ & $\mathrm{C} 1$ & $\mathrm{C} 2$ & $\mathrm{C} 3$ \\
\hline \multicolumn{10}{|l|}{ DNA (ng/ $/ \mathrm{L})$} \\
\hline Initial concentration & 125.8 & 21.6 & 56.2 & 70.2 & 33.7 & 56.2 & 89.8 & 21.6 & 123.2 \\
\hline Final concentration & 3.0 & 0.03 & 1.9 & 2.3 & 0.8 & 1.9 & 2.91 & 0.2 & 3.6 \\
\hline Total reduction (\%) & 98 & 99.9 & 97 & 97 & 99.7 & 97 & 97 & 99 & 97 \\
\hline \multicolumn{10}{|l|}{ RNA (ng/ $\mu \mathrm{L})$} \\
\hline Initial concentration & 24.2 & 21.6 & 6.4 & 24.2 & 21.6 & 6.4 & 24.2 & 21.6 & 6.4 \\
\hline Final concentration & 0.4 & 0.0 & 0.5 & 0.8 & 0.0 & 0.3 & 0.4 & 0.0 & 0.3 \\
\hline Total reduction (\%) & 98 & 100 & 92 & 97 & 100 & 95 & 98 & 100 & 95 \\
\hline
\end{tabular}

To verify whether the amounts of DNA remaining in the RNA samples were sufficient to affect the accuracy of the subsequent processes such as reverse transcription reaction and real-time PCR, conventional PCR was performed with the RNA samples purified with DNase I. The results were visualized on a $1.5 \%$ agarose gel (Figure 2).

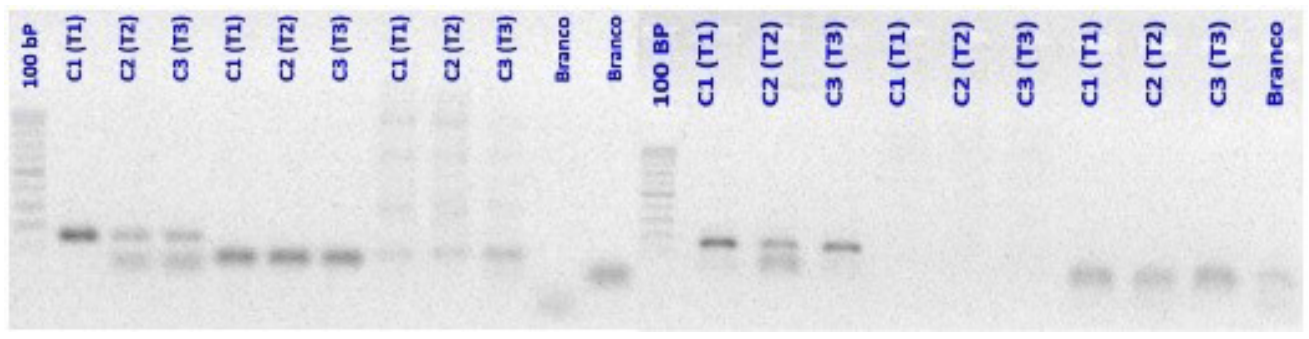

Figure 2. DNA amplification of RNA samples after treatment with DNase I using PCR. DNA ladder 100 bp; C1 (T1), C2 (T2), and C3 (T3) amplified fragments of the cultivars 1, 2, and 3 after treatment with 0.02, 0.04, and 0.06 $\mu \mathrm{L}$ DNase I (T1, T2, and T3, respectively); Primers used for PSII 10 (162 bp), HSP (78 bp), and GAPDH (101 bp) genes. Branco was used as negative control.

Comparison of the quality of the extracted RNA to the quality of the purified RNA, after treatment with DNase I, showed that the organic extraction method provided RNA samples with low levels of protein contamination, indicated by the $\mathrm{A}_{260 / 280}$ ratios (Table 2). These ratios were not significantly different from the $\mathrm{A}_{260 / 280}$ ratios obtained after the three treatments $(\mathrm{P}=0.07)$. Similarly, there were no significant differences in the $\mathrm{A}_{260 / 280}$ ratios between the treatments: treatments 1 and $2(\mathrm{P}=0.75)$, treatments 1 and $3(\mathrm{P}=0.44)$, and treatments 2 and $3(\mathrm{P}=0.23)$.

There were significant differences $(\mathrm{P}=0.0003)$ between the $\mathrm{A}_{260 / 230}$ ratios, before and after the treatments (Table 2). However, no significant differences in these ratios were observed between the three treatments: treatments 1 and $2(\mathrm{P}=0.48)$, treatments 1 and $3(\mathrm{P}=0.43)$, and treatments 2 and $3(\mathrm{P}=0.95)$. The quality of RNA after DNase I treatment was checked on $1 \%$ agarose gel (Figure 3), which clearly showed RNA degradation after the treatments.

Analysis of the amplification curve (Figure 4) allowed inference of the amplification efficiency of the cDNA transcribed from the RNA samples purified with DNase I (Wong and Medrano, 2005). There was a difference between the initial amplification cycles of the two samples used for qRT-PCR. 


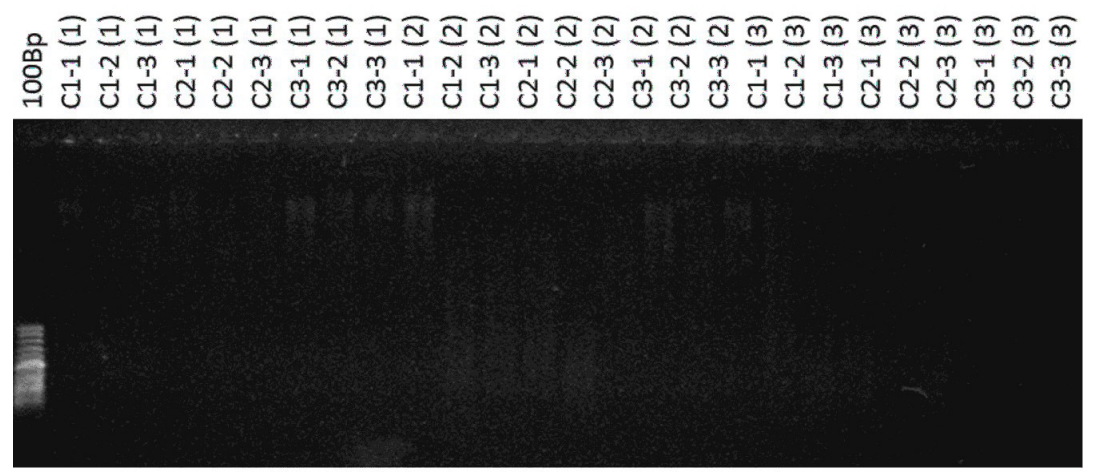

Figure 3. Quality of RNA after DNase I treatment. C1-1, C1-2, and C1-3 for cultivar 1; C2-1, C2-2, and C2-3 for cultivar 2; and C3-1, C3-2, and C3-3 for cultivar 3, for replicates 1, 2, and 3, respectively. The numbers in the parentheses indicate the treatment with $0.02,0.04$, and $0.06 \mu \mathrm{L}$ DNase I (1, 2, and 3, respectively).

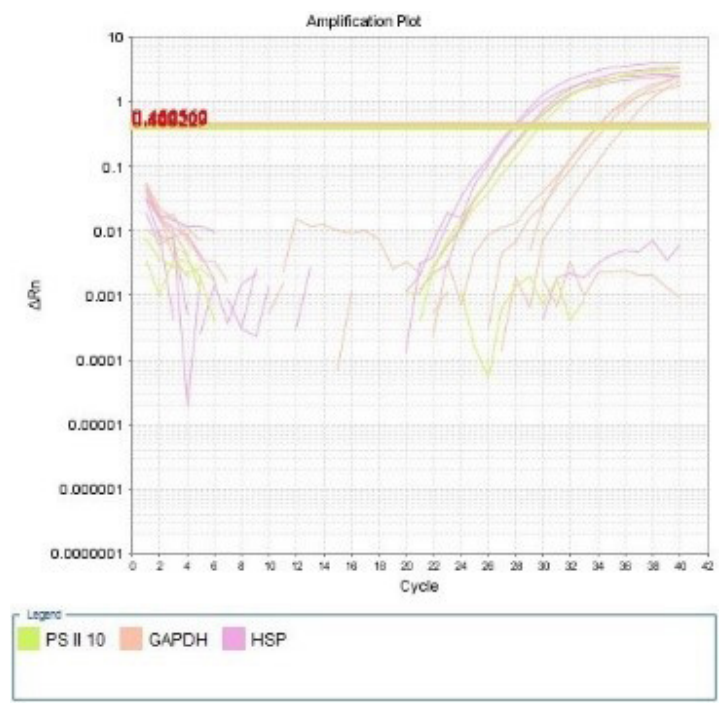

Figure 4. Amplification curve for quantitative real-time PCR of two RNA samples treated with DNase I and reverse transcribed to cDNA using three primer sets for PSII 10 and HSP as target genes and GAPDH as the reference gene. $\mathrm{C}_{\mathrm{T}}$ indicates the cycle threshold.

In addition, it verified the obvious exponential and plateau phases seen for both samples. For the $\mathrm{C} 1$ sample, the amplification of the $H S P$ gene initiated at cycle 28 , whereas for the $\mathrm{C} 2$ sample the amplification of the PSII 10 gene initiated during cycle 29. The cycle threshold for both samples was 0.46056 .

The data from the dissociation curve (Figure 5) allowed analysis of the specificity of the reaction, taking into account the primers, reaction conditions, and the samples used in qRTPCR (Wong and Medrano, 2005). A variation in the dissociation curve profiles was observed between the two samples. The melting temperature was determined as $84.4^{\circ} \mathrm{C}$. Furthermore, nonspecific amplifications were observed in qRT-PCR. 


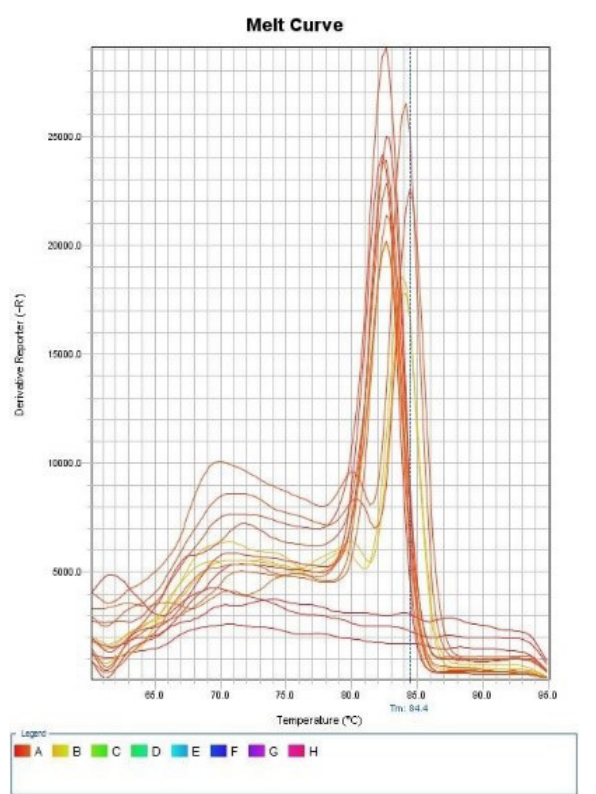

Figure 5. Melting curve for the quantitative real-time PCR of two RNA samples treated with DNase I and reverse transcribed to cDNA.

\section{DISCUSSION}

The results presented in Table 2 indicate that there were variations in the RNA concentrations of the three cultivars. Portillo et al. (2006) reported that differences in the RNA concentration and quality, among samples or treatments, may result from differences in the extraction efficiency and/or quality of the RNA. Furthermore, Syazana et al. (2014) reported that if RNA yield is lower than expected, the homogenization may not have been successfully completed or maceration of the material may not have been properly performed. These steps often vary, depending on the type of sample used for extraction and the type and initial volume of the lysis buffer utilized. Therefore, differences in RNA concentrations in the sugarcane cultivars could be explained by the differences in extraction efficiency, especially in homogenization, lysis, and weighing of the samples. As the samples were collected in the RNAlater ${ }^{\mathbb{R}}$ solution, it was difficult to establish the exact weight of the material $(100 \mathrm{mg})$ for all samples.

Comparing the RNA concentrations obtained from this study with those obtained from other RNA extraction trials on sugarcane (Damaj et al., 2009; Sah et al., 2014), it was observed that the organic extraction method used in our study allowed RNA isolation at lower concentrations. Studies suggest that increasing the amount of initial sample and maceration precession at the lowest possible temperature can result in extraction of large quantities of RNA (Damaj et al., 2009; Sah et al., 2014).

The analysis of agarose gel indicated the presence of two distinct RNA bands, $28 \mathrm{~S}$ and $18 \mathrm{~S}$, and genomic DNA bands that were observed at the top of the gel (Figure 1). Tavares et al. (2011) highlight that the organic extraction method is based on liquidliquid extraction, which may result in incomplete phase separation and increase the level of genomic DNA contamination. 
Huang et al. (1996) demonstrated that the inactivation of DNase I at $95^{\circ} \mathrm{C}$ for $5 \mathrm{~min}$ also affects the integrity of the mRNA, which might explain the degradation of RNA after treatment with DNase I (Table 3). The authors then conducted a study to optimize the treatment of RNA with DNase I. The results indicated that thermal denaturation of the enzyme at $75^{\circ} \mathrm{C}$ for 5 min preserved almost all of the mRNA, whereas heat denaturation at $95^{\circ} \mathrm{C}$ for $5 \mathrm{~min}$ inactivated approximately $80 \%$ of the mRNA. Finally, thermal denaturation at $55^{\circ} \mathrm{C}$ for 10 min did not completely denature DNase I. Therefore, in this study, the inactivation of DNase by heating at $65^{\circ} \mathrm{C}$ for $10 \mathrm{~min}$ might have influenced the degradation of the RNA samples.

Analysis of PCR amplification gels showed that the amount of DNA present in the RNA samples treated with DNase I was enough to amplify the target genes through PCR, indicated by the DNA bands present in the gels (Figure 2). For each PCR, three pairs of primers were used. The primers had different amplicon sizes and some of them generated nonspecific products that might have resulted from the formation of secondary structures. Some bands were also observed in the negative control (Figure 2). One possible explanation could be the formation of secondary structures, such as dimers, hairpins, and cross-dimers, as the analysis of the primers by NetPrimer software showed that the primers could form these structures.

The changes in the $\mathrm{A}_{260 / 280}$ and $\mathrm{A}_{260 / 230}$ ratios after treatment with DNase I probably resulted from the presence of residues of the components of the DNase I mixture. Nybo (2012) reported that to accurately measure the optical density of RNA after treatment with DNase, it is necessary to perform RNA purification again to remove DNase, bovine serum albumin, EDTA, carbohydrates, phenol, guanidine $\mathrm{HCl}$, and buffer residues from the samples, because all these components change the quantification based on optical density. These components absorb light at 280 and $230 \mathrm{~nm}$ wavelengths and therefore change the values of the ratios. Furthermore, degraded RNA fragments and dNTPs also absorb light at $280 \mathrm{~nm}$.

The low $\mathrm{A}_{260 / 230}$ ratios of the three cultivars $(\mathrm{C} 1, \mathrm{C} 2$, and $\mathrm{C} 3-1.6,1.2$, and 0.7 , respectively) suggest that the samples were contaminated with polysaccharides and polyphenols (Table 2). These results were in agreement with those of a previous study on RNA extraction from sugarcane using organic reagents (Damaj et al., 2009), which also showed RNA with high levels of contamination with these components. This study also suggests that stresses, such as infections by pathogens or water and nutrient deficiency, may increase the accumulation of polysaccharides and secondary metabolites, particularly phenols, in plants.

The qRT-PCR amplification plot showed that even the low RNA concentrations obtained after treatment with DNase, subsequently transcribed to cDNA, were sufficient to generate amplification (Figure 4). Regarding the specificity of the reaction, a good dissociation curve profile was observed, provided by the primers, reaction conditions, and RNA samples that showed small amounts of remaining genomic DNA after treatment with DNase I (Figure 5). However, it was verified that there were some nonspecific amplification products and that some genes were not amplified. The qRT-PCR was repeated and similar results were obtained, which indicated that some of the primers that resulted in two peaks in the dissociation curve need to be redesigned and retested in future studies.

The presence of distinct peaks indicated that different amplification products were produced in the reaction. Opel et al. (2010) showed that a variety of inhibitory mechanisms may occur during PCR, depending on the type of the co-extracted inhibitor. These mechanisms affect the reaction and interfere with the results of the amplification and dissociation curves. For example, Taq inhibitor, binding of the inhibitor to the DNA, dimers, and the effect on the reaction efficiency may generate nonspecific amplification product peaks. As SYBR Green I

Genetics and Molecular Research 15 (4): gmr15049073 
detects all double-stranded DNA, it cannot differentiate between the specific amplified product and the dimers formed during the reaction. Furthermore, the amount of dimers produced also depends on the original concentration of the target DNA samples used in the assay. The lower the amount of target DNA, the greater the amount of dimer products.

As shown in the melting curve (Figure 5), dimers have small fragment size and generally dissociate at lower temperatures compared to the target products. Similarly, nonspecific products, such as remaining genomic DNA, can result in PCR products that dissociate at temperatures above or below the target products. As solutions to these interferences, it is often recommended to collect the amplification data at a temperature at which dimers are dissociated but the specific products are not. The amplification of nonspecific products is usually solved by testing different annealing temperatures, to optimize primer specificity and eliminate the presence of secondary products.

Although the data show that high concentrations of DNase I do not significantly increase its activity to degrade contaminant DNA in RNA samples, we still see some scope for improvement. For example, one apparent limitation of the study was to extract the same and high initial concentration of RNA from samples. Thus, an additional assay needs to be conducted using the same and high starting concentration of RNA, to highlight the results of this study. The purpose of performing qRT-PCR was to standardize the reaction and try to verify the efficiency of amplification of the RNA samples treated with DNase I. As few genes failed to amplify, it is necessary to test more genes. Additionally, the primers resulting in two peaks in the dissociation curve need to be redesigned, to avoid false positive results in the future studies.

\section{CONCLUSIONS}

This study showed that using higher concentrations of DNase I does not increase its efficiency to degrade genomic DNA present in extracted RNA samples. Thus, using 0.02 $\mu \mathrm{L}$ DNase I makes the RNA purification process less costly and allows achievement of similar results as seen for the other two tested concentrations, 0.04 and $0.06 \mu \mathrm{L}$. Therefore, a concentration $0.02 \mu \mathrm{L}$ is recommended for purification of sugarcane RNA, with similar characteristics to the genetic material used in this study. Furthermore, it was found that both low amounts of RNA transcribed into cDNA, and the presence of small amounts of genomic DNA after treatment with DNase did not interfere with amplification by qRT-PCR; however, it did affect the efficiency of qRT-PCR.

\section{Conflicts of interest}

The authors declare no conflict of interest.

\section{ACKNOWLEDGMENTS}

We thank the Molecular Biology \& Biotechnology Laboratory at Embrapa MeioNorte for supporting these experiments and helping in achieving these results, Universidade Federal do Piauí for academic support, and Conselho Nacional de Desenvolvimento Científico e Tecnológico.

Genetics and Molecular Research 15 (4): gmr15049073 


\section{REFERENCES}

Bustin SA and Nolan T (2004). Pitfalls of quantitative real-time reverse-transcription polymerase chain reaction. $J$. Biomol. Tech. 15: 155-166.

Damaj MB, Beremand PD, Buenrostro-Nava MT, Riedel B, et al. (2009). Reproducible RNA preparation from sugarcane and citrus for functional genomic applications. Int. J. Plant Genomics 2009: 765367. http://dx.doi. org $/ 10.1155 / 2009 / 765367$

de Paula MFB, Ságio SA, Lazzari F, Barreto HG, et al. (2012). Efficiency of RNA extraction protocols in different types of coffee plant tissues. Coffee Sci 7: 284-293.

Guo J, Ling H, Wu Q, Xu L, et al. (2014). The choice of reference genes for assessing gene expression in sugarcane under salinity and drought stresses. Sci. Rep. 4: 7042.http://dx.doi.org/10.1038/srep07042

Huang Z, Fasco MJ and Kaminsky LS (1996). Optimization of Dnase I removal of contaminating DNA from RNA for use in quantitative RNA-PCR. Biotechniques 20: 1012-1014, 1016, 1018-1020.

Ling H, Wu Q, Guo J, Xu L, et al. (2014). Comprehensive selection of reference genes for gene expression normalization in sugarcane by real time quantitative rt-PCR. PLoS One 9: e97469. http://dx.doi.org/10.1371/journal.pone.0097469

Martel F, Gründemann D and Schömig E (2002). A simple method for elimination of false positive results in RT-PCR. $J$. Biochem. Mol. Biol. 35: 248-250.

Novais CM and Pires-Alves M (2004). PCR em tempo real. Biotecnolog. Cienc. Desenvolv. 33: 10-13.

Nybo K (2012). DNase-treated RNA. Biotechniques 52: 233-234.http://dx.doi.org/10.2144/000113836

Oliveira JFNC (2013). Caracterização fisiológica e perfil de expressão gênica de cultivares de cana-de-açúcar (Saccharum spp.) contrastantes para o deficit hídrico. Doctoral thesis, Escola Superior de Agricultura Luiz de Queiroz, University of São Paulo, Piracicaba.

Oñate-Sánchez L and Vicente-Carbajosa J (2008). DNA-free RNA isolation protocols for Arabidopsis thaliana, including seeds and siliques. BMC Res. Notes 1: 93. http://dx.doi.org/10.1186/1756-0500-1-93

Opel KL, Chung D and McCord BR (2010). A study of PCR inhibition mechanisms using real time PCR. J. Forensic Sci. 55: 25-33. http://dx.doi.org/10.1111/j.1556-4029.2009.01245.x

Portillo M, Fenoll C and Escobar C (2006). Evaluation of different RNA extraction methods for small quantities of plant tissue: combined effects of reagent type and homogenization procedure on RNA quality-integrity and yield. Physiol. Plant. 128: 1-7. http://dx.doi.org/10.1111/j.1399-3054.2006.00716.x

Sah SK, Kaur G and Kaur A (2014). Rapid and reliable method of high-quality RNA extraction from diverse plants. Am. J. Plant Sci. 5: 3129-3139. http://dx.doi.org/10.4236/ajps.2014.521329

Syazana MSN, Sulaiman WAW, Halim AS and Sarina S (2014). Skin tissue surface morphology and quality of RNA and protein extracted from fresh and stabilized human cleft lip and palate tissue. Maced. J. Med. Sci 7: 23-28. http:// dx.doi.org/10.3889/MJMS.1857-5773.2014.0351

Tavares L, Alves PM, Ferreira RB and Santos CN (2011). Comparison of different methods for DNA-free RNA isolation from SK-N-MC neuroblastoma. BMC Res. Notes 4: 3. http://dx.doi.org/10.1186/1756-0500-4-3

Wong ML and Medrano JF (2005). Real-time PCR for mRNA quantitation. Biotechniques 39: 75-85. http://dx.doi. org/10.2144/05391RV01

Genetics and Molecular Research 15 (4): gmr15049073 